\title{
The Archaeology of the Pueblo Revolt and the Formation of the Modern Pueblo World
}

\section{Citation}

Liebmann, Matthew Joseph, Robert W. Preucel. 2007. The archaeology of the Pueblo Revolt and the formation of the modern Pueblo world. Kiva 73(2): 195-217.

\section{Published Version}

http://www.altamirapress.com/rla/journals/kiva/Index.shtml

\section{Permanent link}

http://nrs.harvard.edu/urn-3:HUL.InstRepos:3693473

\section{Terms of Use}

This article was downloaded from Harvard University's DASH repository, and is made available under the terms and conditions applicable to Other Posted Material, as set forth at http:// nrs.harvard.edu/urn-3:HUL.InstRepos:dash.current.terms-of-use\#LAA

\section{Share Your Story}

The Harvard community has made this article openly available.

Please share how this access benefits you. Submit a story.

\section{Accessibility}




\title{
THE ARCHAEOLOGY OF THE PUEBLO REVOLT AND THE FORMATION OF THE MODERN PUEBLO WORLD
}

\author{
Matthew Liebmann \\ College of William and Mary \\ and \\ Robert W. Preucel \\ University of Pennsylvania
}

\author{
Kiva, 2006 \\ Current Research in the Northern Rio Grande, New Mexico \\ Edited by B. Vierra and M. Bremer
}

\begin{abstract}
The Pueblo Revolt and its aftermath (AD 1680-1696) was a crucial period in the history of the American Southwest. Previous studies of this era have focused primarily on the causes of the Revolt, often casting it as an isolated and anomalous event. This article takes a different approach, investigating the effects of the Revolt era on Pueblo cultures and communities in the years, decades, and centuries that followed the uprising of 1680 . Recent archaeological research on ancestral Keres and Jemez villages in the northern Rio Grande reveals evidence for cultural revitalization and ethnogenesis in the wake of the Revolt. The long-term implications of Revolt-era diaspora and migration are also reviewed, as well as the role of memory and oral traditions of this tumultuous period in the formation of modern Pueblo cultures and communities.
\end{abstract}


The Pueblo Revolt era (A.D. 1680-1696) has fascinated scholars of the American Southwest for more than a century. The events of the Revolt and Spanish reconquest have been studied by Borderlands historians (Bancroft 1889; John 1975; Sando 1979; Jones 1989; Gutiérrez 1991; Riley 1999; Weber 1999a) as well as anthropologists (Bandelier 1892; Spicer 1962; Dozier 1970), and have been the subject of many books aimed at popular audiences (Silverberg 1970; Folsom 1973; Baldwin 1995; Roberts 2004, Sando and Agoyo 2005). Much of this literature has focused on the causes of the Pueblo Revolt (Weber 1999b:8), debating the role of economics versus religion (Bowden 1975), the identities of its leaders (Chavez 1967; Beninato 1990), and the impacts of shortversus long-term factors on the timing of the Revolt (Garner 1974; Knaut 1995). Far less attention has been paid to the changes that occurred in the Pueblo world between 1680 and 1696, or to the enduring effects of these years on the formation of modern Pueblo cultures and communities.

With few exceptions, previous historical studies of the Pueblo Revolt era have been based upon the same body of documentary evidence, consisting of Spanish military journals (Hackett and Shelby 1942; Kessell and Hendricks 1992; Kessell et al. 1995, 1998) and Franciscan ecclesiastical correspondence (Hackett 1937; Espinosa 1988). This dependence upon the textual record has resulted in histories of the Pueblo Revolt as seen through Spanish eyes, in which Pueblo perspectives are included only via European interlocutors and translators (Weber 1999b:9). Yet there are significant and obvious biases in these documents, as the Spanish authors attempted to rationalize their defeat and justify the reconquest of the region. Primary texts tend to represent the Revolt as an 
anomalous event and deny the long history of Pueblo resistance to Spanish economic oppression and religious persecution.

Furthermore, the textual record contains very little information regarding the changes in Pueblo cultural and social formations that occurred between 1680 and 1692. The Spaniards were in exile during these years, making only a few short and poorly documented forays into the northern Rio Grande region, while the indigenous population did not record their histories in writing. As a result, historical studies have focused on the "bookends" of the Revolt era, jumping from the events of 1680-81 to Vargas's ritual repossession in 1692 with the turn of a single page, leaving the intervening years of Pueblo independence largely unexamined. As a result, many historical studies have depicted the Revolt as a temporary setback in the expansion of the Spanish empire (Bolton 1916; Bowden 1975; Garner 1974; but see Knaut 1995). From an anthropological perspective, however, the social practices of Pueblo peoples during these years are crucial for understanding the long-term effects of the Revolt era on the development of modern Pueblo cultures.

In recent years, archaeological research into the Pueblo Revolt era has begun to redress these deficiencies (Ferguson 1996; Snead and Preucel 1999; Preucel 2000a, 2000b, 2002a; Wilcox 2001; Preucel et. al. 2002; Liebmann et al. 2005; Liebmann 2006). The archaeological record provides a valuable source of data regarding the Revolt era that is independent of Spanish chronicles, allowing a glimpse into the lives of the Pueblo peoples through the material culture they created. This recent research has documented some of the many changes that took place in the Pueblo world in the wake of the Revolt, including migrations, shifts in settlement patterns, new forms of architecture and spatial 
organization, and transformations in ceramic production and trade. These changes had significant and enduring effects on the constitution of Pueblo cultures and communities, many of which reverberate down to the present day.

In order to examine the impacts of this crucial period further, we draw upon our recent archaeological research on ancestral Keres and Jemez Revolt-era villages in the northern Rio Grande. Between 1996 and 2004, we performed collaborative research with the Pueblo de Cochiti (Preucel) and the Pueblo of Jemez (Liebmann), investigating six mesa-top villages constructed and occupied between 1680 and 1696: Kotyiti (LA 295), Kotyiti East (LA 84), Patokwa (LA 96), Boletsakwa (LA 136), Astialakwa (LA 1825), and Cerro Colorado (LA 2048) (Figure 1). The results of our investigations form the core of the interpretations presented below.

\section{CULTURAL REVITALIZATION}

The Pueblo Revolt era was more than just a series of battles between Europeans and Native Americans. It was part of a larger movement to purge the Pueblo world of foreign influence and return to traditional, pre-Hispanic ways of life (Wilcox 1981; Ortiz 1994; Reff 1995; Preucel 2000a; Liebmann 2006). In 1681, Pueblo witnesses identified a Tewa man from San Juan Pueblo named Po'pay as the primary organizer of the rebellion (Hackett and Shelby 1942, 2:233-253). They stated that Po'pay had toured the Pueblos after the Revolt, preaching a message of nativism (the elimination of foreign influence) and revivalism (the introduction of cultural practices thought to have been characteristic of previous generations but not recently present in a social group). He reportedly ordered the Pueblos to: "instantly break up and burn the images of the holy Christ, the Virgin 
Mary and the other saints, the crosses, and everything pertaining to Christianity ... burn the temples, break up the bells, and separate from the wives whom God had given them in marriage and take those whom they desired" (Hackett and Shelby 1942:247).

Many of the Pueblos heeded Po'pay's nativistic call. Churches were sacked and destroyed in the pueblos of Taos, Picuris, San Juan, Santa Clara, San Felipe, Sandia, Isleta, Senecú, Socorro, Alamillo, Sevilleta, Alameda (Hackett and Shelby 1942), Pecos (Hayes 1974), and among the Zuni (Smith et al. 1966) and Hopi pueblos (Montgomery et al. 1949). At Sandia the people symbolically crippled the friars by hacking the arms off a statue of St. Francis with an axe, and whipped a crucifix with such ferocity that all the paint and varnish was removed (Hackett and Shelby 1942, 1:177-178). The people of Senecú scalped a figure of the crucified Christ and felled a large cross that stood in the main plaza, dumping it unceremoniously in the cemetery-powerful signs that indeed, as Po'pay proclaimed: "Now the God of the Spaniards, who was their father, is dead" (Hackett and Shelby 1942, 2:203-204, 239).

Archaeological evidence from the northern Rio Grande suggests that many Pueblos observed the call for revivalism in the wake of the Revolt as well, attempting to "return to the state of their antiquity . . living thus in accordance with the laws of their ancestors" (Hackett and Shelby 1942, 2:248). Architecture appears to have been used as a material expression of this return to ostensibly traditional prehispanic ways of life. Po'pay reportedly implicated the construction of new architecture specifically in his revivalist discourse: "He saw to it that they at once erected and rebuilt their houses of idolatry which they call estufas ... and that they could erect their houses and enjoy abundant health and leisure" (Hackett and Shelby 1942, 2:248). Between 1680 and 1685, 
Keres and Jemez people vacated their mission pueblos at Cochiti, Santo Domingo, and Jemez (Walatowa) and built the new villages of Patokwa, Kotyiti, and Boletsakwa on the surrounding mesas. Documentary evidence suggests that Patokwa and Kotyiti were constructed in 1681 (Hackett and Shelby 1942, 2:236, 306, 360; Kessell et al. 1995:203), and tree-ring data confirms that construction took place at Boletsakwa between 1680 and 1683 (Elliott 2002:54), and at Kotyiti between 1680 and 1685 (Preucel 1998:32). The layout of these three pueblos is remarkably similar (Figure 2). All display corresponding patterns of spatial organization, with two plazas bisected by a central roomblock. There are two kivas at Kotyiti, and probably two at Patokwa and Boletsakwa as well. ${ }^{1}$

We think that the correspondence in spatial organization shared among these three pueblos is not a coincidence, but can be attributed to the ideology of revivalism employed by the Pueblos in the wake of the Revolt. The compact, dual-plaza form of Kotyiti, Patokwa, and Boletsakwa was a departure from the dispersed, scattered layouts of the mission villages inhabited immediately prior to the Revolt (Kessell et al. 1995:203; Liebmann 2006). Architectural data (including patterns of wall bonding and abutment) demonstrates that these villages were highly planned, with coordinated construction events that were organized on the communal level (Preucel 1998; Liebmann et al. 2005; see Cameron 1999:207). But what does this dual-plaza form have to do with revivalism, if anything?

It may be that the dual-plaza plan represents an idealized form of what the builders of these pueblos considered to be an archetypal "traditional" prehispanic village. Preucel has suggested that the layout of Kotyiti likely embodies fundamental cosmological principles of the Keres worldview (Snead and Preucel 1999). If this is the 
case, its very architectural form would have reminded Pueblo peoples of their enduring connections to the prehispanic world and affirmed their renewed commitment to a traditional way of life. The dual-plaza plan may even have been equated with White House, the primordial village of mythological time where people lived after emerging from Shipap (White 1932). The replication of this iconic form at Kotyiti, Patokwa, and Boletsakwa suggests that the inhabitants of these pueblos shared a common ideological template, even if the specific meanings may have varied locally. We think that this formal correspondence is evidence of a discourse that emphasized social balance and harmony as a means of reordering their world, which had been thrown into chaos during eight decades of Spanish colonialism.

The restoration of balance was accomplished through the construction of these dual-plaza pueblos, which we believe reflects the dualistic pattern of social organization emphasized in these communities following the Pueblo Revolt. Previous investigations of ancestral Puebloan architecture have used patterns of duality to argue for moiety divisions (Hill 1970:36; Vivian 1970:80-82; Rohn 1971:39-40; Clemen 1976:127-128; Fritz 1978; Lowell 1996:77; Fowles 2005), and we adopt the same argument here. In historical Rio Grande pueblos, the influence of moietal social organization on architecture and settlement is well documented, with dwellings arranged around two plazas (Parsons 1929:91; White 1962:183; Dozier 1970:155), or in two groups, one for each moiety (Fox 1967:12, 14; Brown 1979:273; Jorgensen 1980:191-92, 239; Fowles 2005:28-29). As Lowell (1996:82) notes, communities utilizing a dual system of social organization require physical space in which the two groups (or their representatives) can perform their respective activities. If moieties were important organizational subsystems 
in the Revolt era, we would expect them to influence the architecture constructed during this period, manifested in some type of binary spatial organization (Hill 1970:36). Thus the dual-plaza layout of Kotyiti, Patokwa, and Boletsakwa suggests that a dual division was present in these communities following the Revolt. By analogy to modern Keres and Jemez pueblos, these two plazas likely index a moietal social organization divided into the Turquoise and Pumpkin groups.

The emphasis on moietal social organization in the Revolt-era pueblos seems to have been linked to Po'pay's call for revivalism. Dualism has been identified as a fundamental organizing concept of Rio Grande Pueblo culture, and is related to the maintenance of balance in the ritual and cosmological realms (Ortiz 1969). Moietal divisions structured settlement in at least some Pueblos prior to Spanish colonization (Ortiz 1979:281; Riley 1999:75). This balance was upset by Franciscan missionaries, who actively participated in the disruption of Pueblo ritual life in the seventeenth century (Spicer 1962:160-161; Kessell 1979:110; Gutiérrez 1991:72; Riley 1995:261), with the suppression of Pueblo religion becoming particularly intense in the twenty years preceding the Revolt (Riley 1999:157). Thus we interpret the strong emphasis on duality in the post-Revolt pueblos as an attempt to restore balance, to return to traditional forms of Pueblo social organization that were disrupted by Spanish colonization.

Ceramics played a role in Revolt-era cultural revitalization as well. Capone and Preucel (2002) have argued that Kotyiti women revived traditional motifs on their glazeware ceramics. The best example of this is the double-headed key motif (Figure 3). This motif has considerable antiquity in the Rio Grande glazeware sequence, originating during Glaze B times (A.D. 1400-1450). However, Kidder (1936:227) notes that 
although present, the double-headed key is relatively rare in Glaze E (A.D. 1515-1625) ceramics. During the Revolt period, the double-headed key motif was revived, and had an extremely broad regional distribution. At Kotyiti, more than a third (36\%) of all identified ceramic designs can be classified as a variant of the key motif, and the most common form is the double-headed key (Capone and Preucel 2002:107-108).

Significantly, this design is also present in the ceramic assemblages of Patokwa, Astialakwa, Boletsakwa, and Cerro Colorado. Additionally, this motif is present on contemporaneous wares outside the Jemez and Keres districts as well, and has been identified in the Revolt-era ceramics of the Hopi (Frank and Harlow 1974:P1 X) and Zuni districts (Smith et. al. 1966:Figs 75, 78, 79; Harlow 1973:Pl 32e).

\section{ETHNOGENESIS}

One of the most significant results of the Pueblo Revolt was the creation of new social identities that blurred the traditional linguistic-ethnic boundaries that defined Pueblo village clusters during the first eight decades of Spanish colonization (Ford et. al. 1972; Wilcox 1981). This process, commonly labeled ethnogenesis, has been defined as "not merely a label for the historical emergence of culturally distinct peoples but a concept encompassing peoples' simultaneously cultural and political struggles to create enduring identities in general contexts of radical change and discontinuity" (Hill 1996:1). Ethnogenesis is a creative adaptation that is particularly common among indigenous groups that have been drastically impacted by colonial institutions and agendas (Roosens 1989). 
In colonial New Mexico, the Spaniards deployed ethnic categories in the context of legitimizing their political and economic system. The ascription of a "Pueblo" ethnicity to linguistically and culturally diverse peoples allowed asymmetric social and economic relations between the indigenous and colonial populations to appear both natural and broadly applicable (Wilcox 2001; Preucel et al. 2002). What is distinctive about the Pueblo Revolt is that Po'pay appropriated this Spanish category in order to mobilize disparate villages against their colonizers. Thus the ethnic category of Puebloness was turned on its head to forge political unity and permit collective resistance in 1680.

The breakdown of traditional social boundaries and adoption of new identities during the Revolt era is clearly illustrated in the ceramics of the Jemez region. From 1350-1680, sites along the upper Jemez River and its drainages exhibited ceramic assemblages dominated by a distinctive matte-painted pottery type known as Jemez Black-on-white (Reiter 1938; Lambert 1981; Elliott 1982, 1986, 1991). The distribution of these sites is limited, and widely assumed to correspond to the distribution of Towaspeaking peoples west of the Rio Grande (Mera 1940; Ford et al. 1972; Elliott 1982, 1986), who identified themselves to early Spanish explorers as ethnically Hemes (Hammond and Rey 1940:244). In addition to high percentages of Jemez Black-on-white (averaging around $43 \%$ of pre-Revolt assemblages), these sites also exhibit low proportions of tradewares (around 3\%), suggesting that the Jemez did not participate in substantial ceramic exchange with non-Jemez pueblos during the three centuries leading up to the Revolt (Reiter 1938; Lambert 1981; Elliott 1991). After 1680, however, the production of Jemez Black-on-white decreased significantly (Figure 4), dropping to just 
5.6 percent of the total assemblage at the Jemez Revolt-period sites of Astialakwa and Patokwa. Furthermore, the Jemez engaged in significantly more trade with their nonTowa neighbors following the Revolt than they did prior to 1680 (Liebmann 2006).

This reduction in the manufacture of Jemez Black-on-white is particularly surprising considering the aforementioned resumption of older pottery styles noted at Kotyiti. But rather than a return to traditional ceramic types, Jemez potters adopted new, regionally shared styles during the Revolt era, blurring the long-established boundaries between them and their Keres neighbors (Liebmann 2006). Analyses of ceramics from other sub-regions of the Pueblo world reveal further evidence for the creation of identities that cut across traditional linguistic-ethnic lines in the wake of the Revolt. Barbara Mills cites the adoption of matte-paint polychromes at Acoma and Zuni, as well as the use of feather motifs on post-Revolt ceramics across the Pueblo world as "evidence for a regionwide stylistic horizon . . . and suggests a unity that cross-cuts language groups and other important social differences among the Pueblos" (Mills 2002:95).

Coterminous with this decline of Jemez Black-on-white is an increase in tradewares at Patokwa and Astialakwa. The Rio Grande glazewares offer a striking illustration of this surge in trade. Glazewares were not locally produced within the Jemez Province prior to the Revolt, when they comprised approximately 2.8 percent of Jemez ceramic assemblages (Reiter 1938:103, 108; Shepard 1938:205; Elliott 1991:80). After the Revolt, however, the proportion of glazewares rose to 13 percent of the total Jemez assemblage (Liebmann 2006). A similar pattern occurs with regard to Tewa ceramics. Stylistic studies of Jemez and Tewa wares support the notion that there was little interaction between these regions before 1680 (Futrell 1998; Graves and Eckert 1998; 
Morley 2002:238). Prior to the Revolt, Tewa wares comprised 0.1 percent of documented Jemez assemblages (Reiter 1938:189-192; Elliott 1991:80); but at the Revolt-era pueblos, 5.8 percent of the ceramics hail from the Tewa region. The increase in Tewa wares at Patokwa and Astialakwa provides evidence for new ties between the Jemez and the Tewa peoples forged in the wake of the Revolt. In fact, interaction between these two regions was stronger in the sixteen years following the Revolt than they had been for three centuries prior to 1680 .

Historians have commonly concluded that the pan-Pueblo unity that coalesced in 1680 was short-lived, citing later reports that Po'pay was quickly deposed and that the "Keres, Jemez, Taos, and Pecos were at war with the Tano, Tewa, and Picuris" during the mid-1680s (Sanchez 1983:133; see also Kessell and Hendricks 1992:26). But the comparatively high proportion of Tewa ceramics at the Jemez Revolt-period sites suggests that the new relationships formed between the Tewa and the Jemez endured for much, if not all of the Revolt era, and calls into question the notion that these groups were at war between 1680 and 1696. Furthermore, the archaeological evidence suggests that while some of the Keres did not engage in direct trade with the Tewa during this period, others did. At the Zia-Santa Ana Revolt period site of Cerro Colorado (constructed and occupied between 1689 and 1694), Tewa wares comprised just 0.1 percent of the total ceramic assemblage (Liebmann 2006). Conversely, there is a high percentage of Tewa wares at Kotyiti (Capone and Preucel 2002), and petrographic analysis indicates that some of these may have been locally manufactured-meaning that Tewa potters were probably living side-by-side with the Keres from Cochiti during the period of Pueblo Independence (Preucel in press). Thus the archaeological record 
provides a more refined picture of inter-pueblo relations during the Revolt era than that derived from documentary accounts alone. New relationships were established among many Pueblos in the wake of the Revolt that crossed traditional linguistic-ethnic lines, as exemplified by the increased trade among the Jemez, Tewa, and Keres of Kotyiti, which was likely related to the emergence of new, pan-Pueblo identities that occurred after 1680. If any of the Keres were at war with the Tewa it was probably the Zia and Santa Ana people of Cerro Colorado, who, along with San Felipe, later allied themselves with the reconquering Spaniards in the 1690s.

\section{DIASPORA AND RETURN MIGRATION}

The new identities that emerged during the Revolt era were largely the result of the intermixing of previously discrete Pueblo groups. The years following the Pueblo Revolt witnessed one of the greatest episodes of migration and reorganization in the recorded history of the Southwest (Herr and Clark 1997). Whole communities vacated their mission pueblos and established new villages in defensive positions on high mesas (Liebmann et al. 2005). Schroeder (1972) identifies these villages as refugee communities and considers them a new form of settlement since they were composed of peoples from several different home-villages. Spanish documents indicate that the population of Kotyiti was comprised of people from Cochiti, San Felipe, and San Marcos (Kessell and Hendricks 1992:515); Boletsakwa was inhabited by people from Jemez and Santo Domingo (Kessell et al. 1995: 416, 445); and Cerro Colorado housed people from Zia, Santa Ana, and Santo Domingo (Kessell and Hendricks 1992: 431, 518-520; Kessell et al. 1995:113). While Patokwa was inhabited primarily by the Towa-speaking Jemez, 
"Apaches" (likely Navajos) and Santo Domingo people were reportedly lodged there in 1692 as well (Kessell and Hendricks 1992:521-522), although this may have been a temporary arrangement.

In addition to the wholesale migration of individual pueblos, smaller groups, such as families and clans, left their traditional homes to journey to remote regions and take up residence with their Apache, Navajo, and Pueblo allies. Some of these groups returned to their mission villages after Diego de Vargas's reconquest campaigns. Others returned in the eighteenth century, and still others never returned at all. The results of this diaspora are expressed in the social composition of contemporary pueblos and thus played a major role in the constitution of the modern Pueblo world.

Many of the Pueblo communities familiar to us today were founded in the aftermath of the Pueblo Revolt. At Hopi, the village of Hano was settled by Tewa refugees from the Rio Grande (Dozier 1966), and the villages of Walpi, Shungopovi, and Mishongovi moved from springs on or near the valley floor to the mesa tops on First and Second Mesas where they remain today (Brew 1979:522), while Shipaulovi was established on Second Mesa (Spicer 1962:192). In the Zuni region, the villages of Hawikuh, Kechiba:wa, Kyaki:ma, Matsaki, and Halona:wa were all inhabited prior to the Revolt. After 1680, they coalesced at the mesa of Dowa Yalanne, where they constructed a single new village (Ferguson 1996). Following the reconquest, the Zuni people vacated this village and together moved back down to reoccupy Halona:wa (modern Zuni Pueblo) as a single community. This involved a major reorganization of Zuni society in order to accommodate the unification of clans, medicine societies, and priesthoods (Ferguson 1996:30). Similarly, Laguna Pueblo appears to have been founded sometime between 
1680 and 1692. According to Ellis approximately 100 refugees from Cochiti, Cieneguilla, Santo Domingo, and Jemez fled to Acoma during the Revolt period. By 1697 some had continued on to Zuni, but the remainder left and founded Laguna near a beaver dam on the San Jose River (Ellis 1979:438). Three villages were established by Pueblo people who accompanied the Spaniards south during their retreat to El Paso del Norte between 1680 and 1682: Socorro del Sur, Senecu del Sur, and Ysleta del Sur (Hackett and Shelby 1942, Spicer 1962), the last of which persists today as the home of the modern Tigua tribe (Houser 1979).

Entire regions were largely depopulated during this period as well. This was most pronounced in the Piro district. The people of Socorro who did not join the Spaniards took refuge at Isleta, Cieneguilla, and Acoma (Hackett and Shelby 1942:203-7). In the Galisteo district the Tano villages of San Marcos, Galisteo, San Lazaro, and San Cristobal were all left vacant (Nelson 1916). The people from Galisteo Pueblo moved first to Santa Fe, then proceeded to the Española valley, and finally to Hopi where they established Hano (Tewa Village) on First Mesa in 1700 (Dozier 1966). The Picuris people moved out onto the plains of modern-day Kansas where they reoccupied the village known as Cuartelejo (Witty 1983).

It was not only new Pueblo communities that formed out this tumultuous era; the origins of the Navajo Jemez Clan (Ma'ii Deeshgiizhnii, "Coyote Pass People") have been traced to the Revolt period as well (Brugge 2002:9). A small number of Pueblo refugees probably lived with the Navajo at Tapacito Ruin (LA 2298), a Navajo pueblito with treering dates of 1694 (Towner and Dean 1992). Towner (2003:206) suggests that refugees from the battle at Astialakwa may have begun construction at Tapacito within a few 
weeks of the battle, which occurred on July 24, 1694 (Kessell et al. 1998:324-328).

Spanish military journals of the early eighteenth century also document the presence of Jemez people living with the Navajo in this area in 1705 (Hendricks and Wilson 1996).

Many of these migrations were short-lived. The Spaniards went to considerable efforts to persuade people to return to their mission village homes from where they could be more easily administered (Herr and Clark 1997). The Picuris who had fled to Cuartelejo were reestablished at their home pueblo in 1707 (Witty 1983). Similarly the Sandia people who had left the Rio Grande and built the village of Payupki on Second Mesa were returned to their home pueblo in 1748 (Bloom 1931:159-160). These people were known in their home community as the "Moquinos," marking their flight to Hopi (Moqui) lands (Sando 2005:49). Although these migrations were temporary, they did result in the exchange of knowledge and ceremonies that persist to the present day. The Hemis Kachina among the Hopi is generally regarded to have originated with the Jemez (Dockstader 1954:13) and was likely introduced to the Hopi when a group of Jemez migrated there near the end of the Revolt era (Bloom and Mitchell 1938:108). When Jemez and Tiwa refugees were marched home by the Spaniards twenty years later, they brought with them new dances from the Hopi pueblos that are still performed today (Dutton 1936; Sando 2005:49).

\section{MEMORY AND MEANINGS IN THE MODERN PUEBLOS}

Viewing the Pueblo Revolt as an isolated incident, a failed attempt to permanently expel Europeans from the Pueblos, or a temporary setback to Spanish colonization of the Southwest ignores its enduring significance to contemporary Pueblo peoples. The 
importance of these years is attested by the many oral traditions regarding the Revolt era preserved by the modern Pueblos (Preucel 2002b:7-9). Previous text-based studies have consistently maintained that memories of the Pueblo Revolt are not generally retained in Pueblo oral traditions (Kessell 1989:135; Weber 1999b:8; Roberts 2004:148). But simply because Pueblo oral traditions are not circulated as widely and openly as Spanish accounts of the Revolt does not mean they do not exist. Recent studies of memory have argued that it is often used to heal social ruptures and establish the sense of a coherent cultural whole (van Dyke and Alcock 2003:3), and that it is commonly used to mediate the persistent tensions in the individual and community dialectic (Basso 1996). Yet memory is not monolithic and conflicting versions of myth and history often coexist, usually in support of specific interests. In Pueblo society, oral traditions are often specific to particular clans, medicine societies, and even families and their telling is tightly controlled.

In our research, we have noted and recorded several oral accounts of the Revolt that are directly related to the villages we have been studying. Some of the accounts told at Cochiti today are virtually identical to those recorded by Ruth Benedict in the early twentieth century. For example, the stories of "How they came up from Frijoles," "How they came down from the mesa," and "The first priest at Cochiti" all contain accounts of the Revolt period that mention Kotyiti (Benedict 1931). Similarly, Sando (1982:120) recounts Jemez oral traditions regarding the reconquest battle at Astialakwa that accords with versions recorded in 1849 (Simpson 1852:22) and 1874 (Leow 1875:344). More recently, Madalena (2003) has published oral traditions of the 1694 battle that reveal details not recorded in the Spanish versions of these events (Kessell et al. 1998:324-327). 
The maintenance of these oral traditions indicates that the Revolt is a vital and ongoing component of Pueblo identity.

The significance of the Revolt to the Pueblo people was most clearly demonstrated in 1980 when they commemorated its tercentennial anniversary. Their goals were to provide a focus for Pueblo people to examine their heritage and to reaffirm their beliefs and values; to further a broader understanding of Pueblo culture by promoting cultural identity, human dignity, and social viability; to draw attention to the unique issues and concerns of Pueblo communities; and to clarify issues that structure Pueblo and non-Pueblo relations (Agoyo 1980). The highlight of the event was the ceremonial run in which Pueblo people ran from Taos to Hopi re-creating the carrying of the knotted cords which signified the time remaining before the Revolt. The modern Pueblo runners carried a pouch with a buckskin cord with two knots commemorating the day when the two Tesuque youths, Catua and Omtua, were captured by the Spaniards and put to death (Hackett and Shelby 1942, 1:3-5)

More recently, the Pueblos have joined together to support a statue in honor of Po'pay that is now being displayed in the United States Capitol building. In 1997, Herman Agoyo and other Pueblo leaders petitioned the New Mexico Legislature to select Po'pay as the subject of the state's second statue in the National Statuary Hall Collection. The legislature agreed and created the New Mexico Statuary Hall Commission to raise the necessary funds. In 1999, Cliff Fragua of Jemez Pueblo was awarded the commission to sculpt the statue. The statue was unveiled in the rotunda on September 23, 2005 (Sando and Agoyo 2005; Figure 5). 


\section{CONCLUSIONS}

Previous studies have noted some of the more immediate effects of the Pueblo Revolt in the new rapprochement that tacitly emerged between the Pueblos and Spaniards in the eighteenth century. No longer were Pueblo people subjected to the exploitive practices of encomienda and repartimiento (Anderson 1985). Franciscan missionaries became more accommodating of Pueblo religion as well, and less inclined to demand strict allegiance to Christianity (Norris 2000). But Spanish colonial policies were not the only institutions transformed as a result of the Revolt. Archaeological evidence suggests that the wake of the Revolt witnessed significant changes in Pueblo cultural and social formations as well. Indeed, the transformations that occurred in the Pueblo world between the Revolt and the Spanish reconquest continue to resound down to the present day.

As we have attempted to demonstrate, the incorporation of archaeological data and Pueblo oral histories alongside textual evidence can help to develop new understandings of the Pueblo Revolt and its aftermath. This crucial period had considerable effects on the constitution of Pueblo culture and society in both the short and long terms. Following the Revolt, the social practices of cultural revitalization and ethnogenesis that occurred among the Jemez and Keres Pueblos resulted in profound changes that shaped architecture, ceramic production and trade, and Pueblo identities into the eighteenth century. This period also witnessed the last large-scale shift in settlement in the long history of Pueblo migration, forging new alliances among the Pueblos and giving shape to contemporary Pueblo cultures. Thus the Pueblo Revolt era forms a crucial bridge between the Contact period and the modern Pueblo world. This has 
implications for archeological studies of pre-Hispanic Pueblos as well, as analogies with modern Pueblos depend on an accurate understanding of the changes that occurred during the seventeenth century—-something we are only just beginning to develop.

\section{Acknowledgements}

We would like to thank Brad Vierra and Mike Bremer for their kind invitation to participate in this themed issue, as well as Steve Lekson and an anonymous reviewer for their thoughtful comments. We especially appreciate the ongoing support of the Pueblo of Cochiti Tribal Council and Environmental Protection Office as well as the Pueblo of Jemez Department of Resource Protection, Cultural Resource Advisory Committee, and Tribal Administration. Support for this research was generously provided by the Wenner-Gren Foundation for Anthropological Research, the National Science Foundation, the University of Pennsylvania Museum of Archaeology and Anthropology, the Louis J. Kolb Foundation, and the American Philosophical Society. 


\section{REFERENCES CITED}

Agoyo, $\mathrm{H}$.

1980 The Tricentennial Year in Pueblo Consciousness. El Palacio 86:27-31.

Anderson, H. A.

1985 The Encomienda in New Mexico, 1598-1680. New Mexico Historical Review 60(4):353-377.

Baldwin, L.

1995 Intruders Within: Pueblo Resistance to Spanish Rule and the Revolt of 1680. Franklin Watts, New York.

Bancroft, H. H.

1889 History of Arizona and New Mexico 1530-1888. The History Company, San Francisco.

Bandelier, A. F.

1892 Final Report of Investigation among the Indians of the Southwestern United States, Carried on Mainly in the Years from 1880 to 1885. Part II. Papers of the Archaeological Institute of America, American Series, Vol. IV. University Press, Cambridge.

Basso, K.

1996 Wisdom Sits in Places: Landscape and Language Among the Western Apache. University of New Mexico Press, Albuquerque.

Benedict, R.

1931 Tales of the Cochiti Indians. Bureau of American Ethnology, Bulletin 98. Washington D. C.

Beninato, $\mathrm{S}$.

1990 Popé, Pose-yemu, and Naranjo: A New Look at Leadership in the Pueblo Revolt of 1680. New Mexico Historical Review 65:417-435.

Bloom, L. B.

1931 A Campaign against the Moqui Pueblos. New Mexico Historical Review 6:158226.

Bloom, L. B., and L. B. Mitchell

1938 The Chapter Elections in 1672. New Mexico Historical Review 13:85-119.

Bolton, H.E. (editor)

1916 Spanish Exploration of the Southwest, 1542-1706. C. Scribner's Sons, New York. Bowden, H. W.

1975 Spanish Missions, Cultural Conflict and the Pueblo Revolt of 1680. Church History 44:217-28.

Brew, J. O.

1979 Hopi Prehistory and History to 1850. In Southwest, edited by A. Ortiz, pp. 514524. Handbook of North American Indians, volume 10, W. Sturtevant, general editor. Smithsonian Institution, Washington, D.C.

Brown, D. H. 
1974 Social Structure as Reflected in Architectural Units at Picuris Pueblo. In The Human Mirror: Material and Spatial Images of Man, edited by M. Richardson, pp. 317-338. Louisiana State University Press, Baton Rouge.

Brugge, D. M.

2002 Jemez Pueblo and the Navajos: Relations Prior to 1800. In Forward into the Past: Papers in Honor of Teddy Lou and Francis Stickney, edited by R.N. Wiseman, T.C. O'Laughlin, \& C.T. Snow, pp.5-16. Archaeological Society of New Mexico Papers 28, Albuquerque.

Cameron, C. M.

1999 Room Size, Organization of Construction, and Archaeological Interpretation in the Puebloan Southwest. Journal of Anthropological Archaeology 18:201-239.

Capone, P. V., and R. W. Preucel

2002 Ceramic Semiotics: Women, Pottery, and Social Meanings at Kotyiti Pueblo. In Archaeologies of the Pueblo Revolt: Identity, Meaning, and Renewal in the Pueblo World, edited by R. W. Preucel, pp. 99-113. University of New Mexico Press, Albuquerque.

Chavez, Fray A.

1967 Pohé-yemo's Representative and the Pueblo Revolt. New Mexico Historical Review 42:85-126.

Clemen, R.T.

1976 Aspects of Prehistoric Social Organization on Black Mesa. In Papers on the Archaeology of Black Mesa, edited by G. J. Gumerman and R. C. Euler, pp. 11335. Southern Illinois University Press, Carbondale.

Dockstader, F. J.

1954 The Kachina and the White Man: A Study of the Influences of White Culture on the Hopi Kachina Cult. Bloomfield Hills, Cranbrook Institute of Science.

Dozier, E. P.

1966 Hano, a Tewa Indian Community in Arizona. Holt, Rinehart and Winston, New York.

1970 The Pueblo Indians of North America. Holt, Rinehart and Winston, New York. Dutton, B. P.

1936 Hopi Dance of the Jemez Indians. Research 1:70-84.

Elliott, M. L.

1982 Large Pueblo Sites near Jemez Springs, New Mexico. Cultural Resources Document no. 3, Santa Fe National Forest.

1986 Overview and Synthesis of the Archaeology of the Jemez Province, New Mexico. Museum of New Mexico Office of Archaeological Studies, Archaeology Notes 51, Santa Fe.

1991 Pueblo at the Hot Place: Archaeological Excavations at Giusewa Pueblo and San Jose de los Jemez Mission, Jemez State Monument, Jemez Springs, New Mexico. Ms. on file, New Mexico State Monuments, Santa Fe.

2002 Mission and Mesa: Some Thoughts on the Archaeology of Pueblo Revolt Era Sites in the Jemez Region, New Mexico. In Archaeologies of the Pueblo Revolt, edited by Robert W. Preucel, pp. 45-60. University of New Mexico Press, Albuquerque.

Ellis, F. H. 
1979 Laguna Pueblo. In Southwest, edited by A. Ortiz, pp. 438-450. Handbook of North American Indians, volume 10, W. Sturtevant, general editor. Smithsonian Institution, Washington, D.C.

Espinosa, J. M. (editor and translator)

1988 The Pueblo Revolt of 1696 and the Franciscan Mission in New Mexico: Letters of the Missionaries and Related Documents. University of Oklahoma Press, Norman.

Ferguson, T. J.

1996 Historic Zuni Architecture and Society: An Archaeological Application of Space Syntax. Anthropological Papers of the University of Arizona, No. 60. University of Arizona Press, Tucson.

Folsom, F.

1973 Red Power on the Rio Grande: The Native American Revolution of 1680. Follet Publishing, Chicago..

Ford, R. I., A. H. Schroeder, and S. L. Peckham

1972 Three Perspectives on Puebloan Prehistory. In New Perspectives on the Pueblos, edited by A. Ortiz, pp. 19-39. University of New Mexico Press, Albuquerque.

Fowles, S. M.

2005 Historical Contingency and the Prehistoric Foundations of Moiety Organization among the Eastern Pueblos. Journal of Anthropological Research 61:25-52.

Fox, R.

1967 The Keresan Bridge: A Problem in Pueblo Ethnology. Humanities Press, New York.

Frank, L. P. and F. H. Harlow

1974 Historic Pottery of the Pueblo Indians: 1600-1880. New York Graphic Society, Boston.

Fritz, J. M.

1978 Paleopsychology Today: Ideational Systems and Human Adaptation in Prehistory. In Social Archaeology: Beyond Subsistence and Dating. Edited by C. Redman, M. Berman, E. Curtin, W. Langhorne, N. Versaggi, and J. Wanser, pp. 37-59. Academic Press, New York.

Futrell, M. E.

1998 Social Boundaries and Interaction: Ceramic Zones in the Northern Rio Grande Pueblo IV Period. In Migration and Reorganization: The Pueblo IV Period in the American Southwest, edited by K. A. Spielmann, pp. 285-292. Arizona State University Anthropological Research Papers No. 51, Tempe.

Garner, V. H.

1974 Seventeenth-Century New Mexico. Journal of Mexican American History 4:4170.

Graves, W. M. and S. L. Eckert

1998 Decorated Ceramic Distributions and Ideological Developments in the Northern and Central Rio Grande Valley, New Mexico. In Migration and Reorganization: The Pueblo IV Period in the American Southwest, edited by K. A. Spielmann, pp. 263-284. Arizona State University Anthropological Research Papers No. 51, Arizona State University, Tempe.

Gutiérrez, R. A. 
1991 When Jesus Came, the Corn Mothers Went Away: Marriage, Sexuality and Power in New Mexico, 1500-1846. Stanford University Press, Stanford.

Hackett, C. W. (editor)

1937 Historical Documents relating to New Mexico, Nueva Vizcaya, and Approaches Thereto, to 1773. Vol 3. Carnegie Institute of Washington, Washington D. C.

Hackett, C. W. (editor) and C. C. Shelby (translator)

1942 Revolt of the Pueblo Indians of New Mexico, and Otermin's Attempted Reconquest, 1680-1682. 2 vols. Coronado Cuarto Centennial Publications, 15401949. University of New Mexico Press, Albuquerque.

Hammond, G. P., and A. Rey (editors)

1940 Narratives of the Coronado Expedition. University of New Mexico Press, Albuquerque.

Harlow, F. H.

1973 Matte-Paint Pottery of the Tewa, Keres and Zuni Pueblos. University of New Mexico Press, Albuquerque.

Hayes, A. C.

1974 The Four Churches of Pecos. University of New Mexico Press, Albuquerque. Hendricks, R. and J. P. Wilson (editors)

1996 The Navajos in 1705: Roque Madrid's Campaign Journal. University of New Mexico Press, Albuquerque.

Herr, S. A., and J. J. Clark

1997 Patterns in the Pathways: Early Historic Migrations in the Rio Grande Pueblos. Kiva 62(4):365-389.

Hill, J. N.

1970 Prehistoric Social Organization in the American Southwest: Theory and Method. In Reconstructing Prehistoric Pueblo Societies, edited by W. A. Longacre, pp. 1158. University of New Mexico Press, Albuquerque.

Hill, J. D.

1996 Introduction: Ethnogenesis in the Americas, 1492-1992. In History, Power, and Identity: Ethnogenesis in the Americas, 1492-1992. edited by J. D. Hill, pp. 1-19. University of Iowa Press, Iowa City.

Houser, N. P.

1979 Tigua Pueblo. In Southwest, edited by A. Ortiz, pp. 336-343. Handbook of North American Indians, volume 10, W. Sturtevant, general editor. Smithsonian Institution, Washington, D.C.

John, E. A. H.

1975 Storms Brewed in Other Men's Worlds. Texas A \& M University Press, College Station.

Jones, O. L.

1989 The Pueblo Revolt of 1696--Una Rebelión Desconocida: A Review Essay. New Mexico Historical Review 64:361-371.

Jorgensen, J. G.

1980 Western Indians: Comparative Environments, Languages, and Cultures of 172 Western American Indian Tribes. W. H. Freeman and Co., San Francisco.

Kessell, J. R.

1979 Kiva, Cross, and Crown: The Pecos Indians and New Mexico 1540-1840. 
University of New Mexico Press, Albuquerque.

1989 Spaniards and Pueblos: From Crusading Intolerance to Pragmatic Accommodation. In Columbian Consequences, Volume 1: Archaeological and Historical Perspectives on the Spanish Borderlands West, edited by D. H. Thomas, pp.127-138. Smithsonian Institution Press, Washington D.C.

Kessell, J. L. and R. Hendricks (editors)

1992 By Force of Arms: The Journals of Don Diego de Vargas, New Mexico 16911693. University of New Mexico Press, Albuquerque.

Kessell, J. L., R. Hendricks, and M. Dodge (editors)

1995 To the Royal Crown Restored: The Journals of Don Diego de Vargas, New Mexico 1692-1694. University of New Mexico Press, Albuquerque.

1998 Blood on the Boulders: The Journals of Don Diego de Vargas, New Mexico 1694-1697. 2 Vols. University of New Mexico Press, Albuquerque.

Kidder, A. V.

1936 The Glaze-Paint, Culinary, and other Wares. In The Pottery of Pecos, Vol. II, edited by A. V. Kidder, pp. 1-383. Yale University Press, New Haven.

Knaut, A. L.

1995 The Pueblo Revolt: Conquest and Resistance in Seventeenth-Century New Mexico. University of Oklahoma Press, Norman.

Lambert, M. F.

1981 Spanish Influences on the Pottery of San Jose de los Jemez and Giusewa, Jemez State Monument (LA 679), Jemez Springs, New Mexico. In Collected Papers in honor of Erik Kellerman Reed, edited by A. H. Schroeder, pp. 215-236. Archaeological Society of New Mexico Papers 6. Albuquerque Archaeological Society Press, Albuquerque.

Liebmann, M.

2006 Burn the Churches, Break up the Bells: The Archaeology of the Pueblo Revolt Revitalization Movement in Colonial New Mexico. PhD. dissertation, University of Pennsylvania, Philadelphia.

Liebmann, M., T. J. Ferguson, and R. W. Preucel

2005 Pueblo settlement, architecture, and social change in the Pueblo Revolt Era, A.D. 1680-1696. Journal of Field Archaeology 30:1-16.

Leow, O.

1875 Report on the Ruins of New Mexico. In Annual Report of the Chief of Engineers to the Secretary of War, vol. II, part 2. U.S. Government Printing Office, Washington D.C.

Lowell, J. C.

1996 Moieties in Prehistory: A Case Study from the Pueblo Southwest. Journal of Field Archaeology 23:77-90.

Madalena, J.

2003 The Battle of Astialakwa-July 24, 1694. Jemez Thunder. July 15, p. 21. Mera, H. P.

1940 Population Changes in the Rio Grande Glaze-Paint Area. Laboratory of Anthropology Technical Series, Bulletin No. 9. Santa Fe.

Mills, B. J.

2002 Acts of Resistance: Zuni Ceramics, Social Identity, and the Pueblo Revolt. In 
Archaeologies of the Pueblo Revolt, edited by R. W. Preucel, pp. 85-98.

University of New Mexico Press, Albuquerque.

Montgomery, R. G., W. Smith, and J. O. Brew

1949 Franciscan Awatovi: The Excavation and Conjectural Reconstruction of a $17^{\text {th }}$

Century Spanish Mission Establishment at a Hopi Indian Town in Northeastern

Arizona. Papers of the Peabody Museum of American Archaeology and

Morley, S. E.

Ethnology, Harvard University Vol. 36. Cambridge, Mass.

2002 Stylistic Variation and Group Self-Identity: Evidence from the Rio Grande

Pueblos. Ph.D. dissertation, University of California, Los Angeles. University

Microfilms, Ann Arbor.

Nelson, N. C.

1916 Chronology of the Tano Ruins, New Mexico. American Anthropologist 18:169176.

Norris, J.

2000 After "The Year Eighty”: The Demise of Franciscan Power in Spanish New

Mexico. University of New Mexico Press, Albuquerque.

Ortiz, A.

1969 The Tewa World. University of Chicago Press, Chicago.

1979 San Juan Pueblo. In Handbook of North American Indians: Southwest Vol. 9 , edited by A. Ortiz, pp. 278-295. Smithsonian Institution, Washington D.C.

1994 The Dynamics of Pueblo Cultural Survival. In North American Indian Anthropology: Essays on Society and Culture, edited by R. J. DeMallie and A. Ortiz, pp. 296-306. University of Oklahoma Press, Norman.

Parsons, E. C.

1929 The Social Organization of the Tewa of New Mexico. Memoirs of the American Anthropological Association 36, Menasha, WI.

Preucel, R. W.

1998 The Kotyiti Research Project: Report of the 1996 Fieldseason. Report submitted to the United States Forest Service, Santa Fe National Forest, Santa Fe and the Pueblo of Cochiti, Cochiti.

2000a Living on the Mesa: Hanat Kotyiti, A Post-Revolt Cochiti Community in Northern New Mexico. Expedition 42:8-17.

2000b Making Pueblo Communities: Architectural Discourse at Kotyiti, New Mexico. In The Archaeology of Communities: A New World Perspective, edited by M. A. Canuto and J. Yaeger, pp. 58-77. Routledge, London.

2002a (editor) Archaeologies of the Pueblo Revolt: Identity, Meaning and Renewal in the Pueblo World. University of New Mexico Press, Albuquerque.

2002b Writing the Pueblo Revolt. In Archaeologies of the Pueblo Revolt: Identity, Meaning, and Renewal in the Pueblo World, edited by R. W. Preucel, pp. 3-29. University of New Mexico Press, Albuquerque.

in press Archaeological Semiotics. Blackwell, Oxford.

Preucel, R. W., L. P. Traxler, and M. V. Wilcox

2002 "Now the God of the Spaniards is Dead": Ethnogenesis and Community Formation in the Aftermath of the Pueblo Revolt of 1680. In Traditions, Transitions, and Technologies: Themes in Southwestern Archaeology, 
Proceedings of the 2000 Southwest Symposium, edited by S. H. Schlanger. University Press of Colorado, Boulder.

Reff, D. T.

1995 The Predicament of Culture and Spanish Missionary Accounts of the Tepehuan and Pueblo Revolts. Ethnohistory 42:63-90.

Reiter, P.

1938 The Jemez Pueblo of Unshagi, New Mexico, with Notes on the Earlier

Excavations at "Amoxiumqua" and Giusewa. Monographs of the School of American Research Number 6. University of New Mexico and the School of American Research, Santa Fe.

Riley, C. L.

1995 Rio del Norte: People of the Upper Rio Grande from Earliest Times to the Pueblo Revolt. University of Utah Press, Salt Lake City.

1999 The Kachina and the Cross: Indians and Spaniards in the Early Southwest. University of Utah Press, Salt Lake City.

Roberts, D.

2004 The Pueblo Revolt: The Secret Rebellion that drove the Spaniards out of the Southwest. Simon and Schuster, New York.

Rohn, A. H.

1971 Mug House: Mesa Verde National Park, Colorado. Washington D.C., National Park Service, United States Department of the Interior.

Roosens, E. E.

1989 Creating Ethnicity: The Process of Ethnogenesis. Frontiers of Anthropology 5, Sage Publications, Newbury Park, CA.

Sanchez, J. C.

1983 Spanish-Indian Relations During the Otermín Administration, 1677-1683. New Mexico Historical Review 58(2):133-151.

Sando, J. S.

1979 The Pueblo Revolt. In Southwest, edited by A. Ortiz, pp. 194-197. Handbook of North American Indians, volume 10, W. Sturtevant, general editor. Smithsonian Institution, Washington, D.C.

1982 Nee Hemish: A History of Jemez Pueblo. University of New Mexico Press, Albuquerque.

2005 The Pueblo Revolt. In Po'Pay: Leader of the First American Revolution. Edited by J. S. Sando and H. Agoyo, pp. 5-53. Clear Light Publishing, Santa Fe.

Sando, J. S. and H. Agoyo (editors)

2005 Po'pay: Leader of the First American Revolution. Clear Light Press, Santa Fe. Schroeder, A. H.

1972 Rio Grande Ethnohistory. In New Perspectives on the Pueblos, edited by A. Ortiz. pp. 41-70. University of New Mexico Press, Albuquerque.

Shepard, A. O.

1938 Technological Notes on the Pottery from Unshagi. In The Jemez Pueblo of Unshagi, New Mexico, with Notes on the Earlier Excavations at "Amoxiumqua" and Giusewa, by P. Reiter, pp. 205-211. Monographs of the School of American Research Number 6. University of New Mexico and the School of American Research, Santa Fe. 
Silverberg, R.

1970 The Pueblo Revolt. Weybright and Talley, New York.

Simpson, J. H.

1852 Journal of a Military Reconnaissance, from Santa Fe, New Mexico, to the Navajo Country, Made with the Troops under Command of Brevet Lieutenant Colonel John M. Washington, Chief of Ninth Military Department, and Governor of New Mexico in 1849. Senate Ex Doc $1^{\text {st }}$ Session $31^{\text {st }}$ Congress, No. 64. Lippincott, Philadelphia.

Smith, W., R. B. Woodbury, and N. F. S. Woodbury

1966 The Excavation of Hawikuh by Frederick Webb Hodge: Report of the HendricksHodge Expedition 1917-1923. Contributions from the Museum of the American Indian Heye Foundation, Vol. XX. New York.

Snead, J. and R. W. Preucel

1999 The Ideology of Settlement: Ancestral Keres Landscapes in the Northern Rio Grande. In Archaeologies of Landscape: Contemporary Perspectives, edited by W. Ashmore and A. B. Knapp, pp. 169-197. Basil Blackwell, Oxford.

Spicer, E.

1962 Cycles of Conquest: The Impact of Spain, Mexico, and the United States on the Indians of the Southwest, 1533-1960.. University of Arizona Press, Tucson.

Towner, R. H.

2003 Defending the Dinetah: Pueblitos in the Ancestral Navajo Homeland. University of Utah Press, Salt Lake City.

Towner, R. H., and J. S. Dean

1992 LA 2298: The Oldest Pueblito Revisited. Kiva 57:315-331.

van Dyke, R., and S. E. Alcock

2003 Archaeologies of Memory: An Introduction. In Archaeologies of Memory, edited by R. van Dyke and S. E. Alcock, pp.1-14. Blackwell Publishers, Oxford.

Vivian, R. G.

1970 An Inquiry into Prehistoric Social Organization in Chaco Canyon, New Mexico. In Reconstructing Prehistoric Pueblo Societies, edited by W. A. Longacre, pp. 5983. University of New Mexico Press, Albuquerque.

Weber, D. J.

1999a (editor) What Caused the Pueblo Revolt of 1680? Bedford/St. Martins, Boston.

1999b Pueblos, Spaniards, and History. In What Caused the Pueblo Revolt of 1680?, edited by David J. Weber, pp. 3-18. Bedford/St. Martins, Boston.

White, L. A.

1932 The Acoma Indians. In $47^{\text {th }}$ Annual Report of the Bureau of American Ethnology for the years of 1929-1930, pp. 17-192. Government Printing Office, Washington D.C.

1962 The Pueblo of Sia, New Mexico. Smithsonian Institution Bureau of American Ethnology Bulletin 184. Washington, D.C.

Wilcox, D. R. and W. B. Masse

1981 A History of Protohistoric Studies in the North American Southwest. In The Protohistoric Period in the North American Southwest A.D. 1450-1700. edited by D. R. Wilcox and W. B. Masse, pp. 1-27. Arizona State University Anthropological Research Papers No. 24. 
Wilcox, M. V.

2001 The Archaeology of the Pueblo Revolt of 1680. PhD. dissertation, Harvard University, Cambridge.

Witty, T. A. Jr.

1983 An Archaeological Review of the Scott County Pueblo. In Bulletin of the Oklahoma Anthropological Society, Vol. XXXII, edited by D. Wyckoff.

Oklahoma Anthropological Society, Muskogee. 


\section{List of Figures}

Figure 1. Revolt-period villages in the Jemez and Keres districts and the mission pueblos from which their populations were derived

Figure 2. Ancestral Jemez and Keres dual-plaza pueblos of the Revolt era: A) Patokwa; B) Boletsakwa; C) Kotyiti. Patokwa is shown as it appeared between 1681 and early 1694. In late 1694, three of the four open corners were sealed by Spanish forces, and a mission church was constructed in the northwest corner (Kessell et al. 1998:335)

Figure 3. Glaze F bowl with doubleheaded key motif from an unnamed Revolt-era site (Laboratory of Anthropology, Museum of Indian Arts and Cultures, Santa Fe)

Figure 4. Comparison of Pre- and Post-Revolt Jemez Ceramic Assemblages. Pre-Revolt data from the pueblos of Unshagi (Reiter 1938) and Giusewa (Elliott 1991); Post-Revolt data from the pueblos of Patokwa and Astialakwa (Liebmann 2006)

Figure 5. Po'pay statue by Cliff Fragua (image courtesy of J. Renteria)

\footnotetext{
${ }^{1}$ The evidence for the west kiva at Patokwa and the south kiva at Boletsakwa is equivocal. While there are visible depressions in these locations on the surface, masonry walls are not presently discernible. Previous investigations at Patokwa by Reginald Fischer in the 1930s concluded that there was a kiva in the west plaza, as evidenced by his map of the site on file at the Laboratory of Anthropology in Santa Fe; similarly, Elliott (2002:53) identifies two kivas at Boletsakwa.
} 